\title{
NOTES
}

\section{THE POLITICAL BOYCOTT: AN UNPRIVILEGED FORM OF EXPRESSION}

Imagine that the $\mathrm{Ku} \mathrm{Klux} \mathrm{Klan}$ in a small southern town has organized a boycott to encourage merchants to join in pressuring the local government to abandon its plan to more fully integrate the work force. The boycott victims are black-owned businesses. Or posit a Nazi boycott of Jewish merchants designed to force those merchants to vote against a Jewish candidate. This note defines these boycotts as political boycotts, for their goal is to coerce political expression.

The Supreme Court of the United States has never directly decided what degree of protection to accord to political boycotts. In its recent opinion in $N A A C P$ v. Claiborne Hardware Co., ${ }^{1}$ however, the Court confronted a pohitical boycott that, unlike those described above, had an unquestionably laudable goal: government support of racial equality. The Claiborne Court suggested, in dictum, that the first amendment protects pohitical boycotts. ${ }^{2}$

This note argues that the Claiborne dictuin is wrong and that the first amendment should not protect participants in political boycotts. A political boycott is a coercive mode of expression that, regardless of its goals, deprives its victims of their freedom to speak and to associate as they please. This note begins by examining the precedent for the Claiborne decision. The note demonstrates that, in situations analogous to a pohtical boycott, courts have denied first amendment protection to forms of conduct which coerce speech or association. ${ }^{3}$ The note then analyzes whether political boycotts merit protection as expressive conduct under the test set out by the Supreme Court in United States v. O'Brien, ${ }^{4}$ and concludes that under this test such boycotts are not protected by the first amendinent. 5 In light of these precedents the note then considers the Claiborne decision itself. ${ }^{6}$ It

1. 458 U.S. 886 (1982).

2. Id. at 915; see infra text accompanying notes 49-58.

3. See infra notes 7-38 and accompanying text.

4. 391 U.S. 367,377 (1968).

5. See infra notes $40-48$ and accoupanying text.

6. See infra notes 49-86 and accompanying text. 
examines the Court's reasoning and suggests that future courts should not follow Claiborne's approach toward political boycotts.

\section{Government Regulation of Coercive Speech: Analogies to Political Boycotts}

A pohitical boycott uses economic coercion to force its victimis to speak or act politically in a way that furthers the goals, not necessarily of the speaker, but of the boycotter. Although the Supreine Court has not explicitly ruled on the legality of political boycotts it has, in inany cases, indicated that the first ainendment does not shield activity intended to coerce individuals to express a particular view.

\section{A. Regulation of Intrusive Expression.}

The Supreme Court has held tliat the first amendment does not absolutely protect a speaker's right to force others to listen to his message. In Kovacs $v$. Cooper ${ }^{7}$ for instance, the Court held that a inumicipal ordinance banning the use of sound trucks did not violate the first ainendinent. ${ }^{8}$ Justice Reed, writing for a divided Court, ${ }^{9}$ held that the inunicipality had a compelling interest in protecting persons within their homes from ainplified inessages. Justice Reed stated that the intrusive nature of this form of expression deprived the listener of his choice of whether to receive the inessage and concluded that for the Court "to enforce freedom of speech in disregard of the rights of others would be harsh and arbitrary in itself." 10 Using similar reasoning, the Court, in Rowan v. United States Post Office Department, ${ }^{11}$ upheld a federal statute that allowed individuals to remove themselves froin commercial mailing lists. The Court rejected the plaintiff inailer's claim of a first amendment right to communicate, stating that "the right of every person 'to be let alone' must be placed in the scales with the right of others to communicate." 12

Political boycotters intend to force others, by economic coercion, to speak out in a certain way about a specific issue. If the first amend-

7. 336 U.S. 77 (1948).

8. Id. at 87.

9. Chief Justice Vinson and Justice Burton joined in Justice Reed's opinion. Justice Frankfurter and Justice Jackson each wrote a separate concurrence.

10. 336 U.S. at 88.

11. 397 U.S. 728 (1970).

12. Id. at 736; see also Lehman v. City of Shaker Heights, 418 U.S. 298, 307 (Douglas, J., concurring)("While petitioner clearly has a right to express his views to those who wish to histen, he has no right to force his message upon an audience incapable of declining to receive it."); Brush v. Pennsylvania State Univ. Bd. of Trustees, 249 Pa. Super. 164, 173, 375 A.2d 810, 815 (1977)(upholding regulation prohibiting door-to-door canvassing in dormitory). 
ment does not guarantee a right to force others to receive a message, then surely it does not immunize political boycotts that seek to coerce their victims, not just to listen, but to express a particular political view.

\section{B. The Constitutionality of Governmentally-Compelled Disclosure of Individuals' Political Beliefs.}

The Supreme Court has repeatedly held that a state's attempts to force individuals to disclose their political beliefs violate the first and fourteenth amendments. In NAACP v. Alabama ex rel Patterson, ${ }^{13}$ the first such "disclosure" case to reach the Court, the state of Alabama had attempted to force an officer of the NAACP to disclose the organization's membership list. Noting that "on past occasions revelation of the identity of [the NAACP's] rank-and-file members has exposed these members to economic reprisal, loss of employment, threat of physical coercion, and other manifestations of public hostility,"14 the Court held that

compelled disclosure of affiliation with groups engaged in advocacy may constitute as effective a restraint on freedom of association as [governmental action which directly abridges that freedoin]. . . . Inviolability of privacy in group association may in many circumstances be indispensable to preservation of freedom of association, particularly where a group espouses dissident beliefs. ${ }^{15}$

Similarly, in Shelton v. Tucker ${ }^{16}$ the Supreine Court held unconstitutional a state law requiring public school teachers to disclose all organizations to which they had belonged in the past five years. The Court stated that public disclosure of the information, "brimging with it the possibility of public pressures upon school boards to discharge teachers who belong to unpopular or minority organizations, would simply operate to widen and aggravate the impairnent of constitutional liberty."17

The Court in NAACP and Shelton thus held the states' actions unconstitutional in part because it viewed the forced disclosure as " 'encouraging' private discrimination against those who espouse ideas with a particular content." 18 The fact that the state is prohibited by the first and fourteenth ainendments from facilitating private discrimma-

13. 357 U.S. 449 (1958).

14. Id. at 462.

15. Id, see also Gibson v. Florida Legislative Investigation Comm., 372 U.S. 539, 558 (1963)(state attempting to force disclosure of NAACP membership list).

16. 364 U.S. 479 (1960).

17. Id. at $486-87$.

18. Karst, Equality as a Central Principle in the First Amendment, 43 U. CHI. L. REv. 20, 43 (1975)(footnote omitted). 
tion which, by punishing people for holding minority views, encourages them to adopt different beliefs, suggests that the analogous private activity designed to coerce political beliefs or expression is not constitutionally protected. Political boycotts, which are directed at coercing political expression, therefore should not be deemed constitutionally privileged activity.

\section{Protecting Employees from Employer-Coerced Political Activity.}

At least thirty-seven states have laws prohibiting private enployers from preventing their employees from engaging in political activitics or coercing their employees to do so. ${ }^{19}$ One court views sucl laws as protecting "the fundamental right of employees to engage in political activity without interference by employers." 20 The few courts that have considered challenges to these laws have readily upleeld their constitutionality. In Lockheed Aircraft Corp. v. Superior Court, ${ }^{21}$ for example, the California Supreme Court upleeld a California statute prohibiting employer coercion of political activities by its employees. ${ }^{22}$ The court found that the "right to ballot would be endangered if citizens were deprived of any incidents of that riglit or if they were hampered in their advocacy of or opposition to neeasures which may bc placed upon the ballot." 23 The court held that the statute is constitutional because it neitler expressly, nor implicitly deprives an employer of his right to free speech.24

Because an employer, by virtue of his control over his employees' job, is in a position to curtail his enuployees' freedon to engage in polit-

19. Carroll, Protecting Private Employees' Freedom of Political Speech, 18 HARv. J. ON LEGIS. 35, 58 (1981). These laws are collected in [2 State Laws] LAB. L. REP. (CCH) \ 43,045 (1982). For an example of a typical statute, see infra note 22.

20. Fort v. Civil Serv. Comm'n, 61 Cal. 2d 331, 335, 392 P.2d 385, 387, 38 Cal. Rptr. 625, 627 (1964); see also Gay Law Studeuts Ass'n v. Pacific Tel. \& Tel., 24 Cal. 3d 458, 487, 595 P.2d 592, 610, 156 Cal. Rptr. 14, 32 (1979).

21. 28 Cal. $2 d$ 481, 171 P.2d 21 (1946).

22. See Cal. Lab. CodE $\S 1101$ (West 1971), which provides: "No employer shall make, adopt, or enforce any rule, regulation, or policy: (a) Forbidding or preventing employees from engaging or participating in politics or from becoming candidates for public office. (b) Controlling or directing, or tending to control or direct the political activities or affiliations of employees." See also CAL. LAB. CODE $\S 1102$ (West 1971), which provides: "No employer shall coerce or influence or attempt to coerce or influence his employees through or by means of threat of discharge or loss of employment to adopt or follow or refrain from adopting or following any particular course or line of political action or political activity."

23. $28 \mathrm{Cal} .2 \mathrm{~d}$ at 486,171 P.2d at 25.

24. Id.; see also Santiago v. Puerto Rico, 154 F.2d 811, 813 (1st Cir. 1946) (upliolding a statute similar to the one considered in Lockheed). The Santiago court remarked that

an employee's right to adhere to the tenets of the political organization of his choice is a basic right in any truly democratic society. To prevent discrimination by an employer against an employee because that employee chooses to joim a particular pohitical party 
ical activity, the Lockheed court's holding is essential for protection of the einployees' political freedoin. The court's reasoning is also readily applied to the regulation of political boycotts; just as a merchant depends on sales to customers for his livelihood, an employee makes his living by selling labor to his employer. Thus there is the saine potential for coercion. Of course, an individual customer may have less economic power over a merchant, and therefore less power to coerce him, than a monopsonistic eniployer has over an employee. But when large numbers of customers agree not to buy from a merchant, their economic power to coerce that merchant equals an employer's economic power over his einployee. ${ }^{25}$ Thus, when the specific goal of the boycotting custoiners is to force the inerchant to engage in or refrain from political activity, the customers effectively deprive the merchant of his political freedom. Because the first amendment does not protect an einployer who atteinpts to coerce his einployees through economic leverage to engage in political activity, it should not immunize the participant in a political boycott who, through economic leverage, seeks to coerce a merchant to engage in political activity.

\section{Regulation of Coercive Labor Activity.}

Courts have consistently held that coercive labor activity is not protected by the first aniendinent, regardless of its communicative aspects. Thus, for example, although most pickets are constitutionally protected, pickets that block individuals froin crossing the picket line, ${ }^{26}$ threaten violence, ${ }^{27}$ or attract large crowds $^{28}$ can constitutionally be

serves to implement and enforce a right which is openly and proudly recognized and

vigilantly defended in a democracy.

Id. The court held that, as apphed to a job applicant who was not hired because of his political activities, the statute does not greatly abridge the employer's freedom and "does not constitute a violation of due process of law or of any clause of the . . . Federal Constitution." Id.; see also Spokane-Idaho Mining Co., 9 Lab. Arb. (BNA) 749, 752 (1947)(recognizing the importance of an employee's freedom to engage in political activity).

25. See, e.g., infra text accompanying notes 88-90.

26. See Machesky v. Bizzell, 414 F.2d 283, 290-91 (5th Cir. 1969).

27. See Milk Wagon Driver's Union Local 753 v. Meadowmoor Dairies, 312 U.S. 287, 292 (1941); Brewer v. Hoxie School Dist. No. 46, 238 F.2d 91, 94 (8th Cir. 1956).

28. See Southern Christian Leadership Conference, Inc. v. A.G. Corp., 241 So. 2 d 619 (Miss. 1970); Rouse Philadelphia, Inc. v. Ad Hoc '78, 274 Pa. Super. 54, 64, 417 A.2d 1248, 1254 (1979), cert. denied, 449 U.S. 1004 (1980).

Additionally, some picketing creates what has been termed the "signal effect." As Justice Douglas explained in Bakery and Pastry Drivers Local 802 v. Wohl, 315 U.S. 769 (1942): "Picketing by an organized group is more than free speech since it involves patrol of a particular locality and since the very presence of a picket line may induce action of one kind or another, quite irrespective of the nature of the ideas which are being dissemmated." Id. at 776 (Douglas, J., concurring); see also International Bhd. of Teamsters, Local 695 v. Vogt, Inc., 354 U.S. 284, 289 (1957). Although the signal effect is certainly less coercive than, for example, enforcing a boycott 
prohibited because they deprive others of the freedom to choose whether or not to cross the picket line. ${ }^{29}$ The reasoning of these cases suggests that because political boycotters seek to coerce rather than merely to persuade their victims to speak and to associate they, too, should not be deemed protected by the first amendment.

In a secondary labor boycott the labor union boycotts a neutral employer (the secondary target) im order to imcrease pressure on the primary target to accede to umion demands. A major reason that courts have found that secondary labor boycotts are not protected by the first amendment is that such boycotts harm disimterested, neutral busimesses and coerce those busmesses imto pressuring the primary target. ${ }^{30}$

In Carpenters Local 213 v. Ritter's Cafe, ${ }^{31}$ for instance, the Supreme Court upheld the application of a Texas antitrust statute to secondary labor picketing. The plaintiff, Ritter, had hired a contractor to construct a building. The defendant umion picketed Ritter's restaurant to protest the contractor's use of nonunion workers on the other job. In the ensuing suit the Court recognized that picketing deserves some constitutional protection. The Court held, however, that Texas could constitutionally "confine the sphere of communication to that directly related to the dispute." 32 To hold otherwise would have been to "allow the disputants in a particular industrial episode to conscript neutrals having no relation to either the dispute or the industry im which it arose." 33

Using similar reasoning the Supreine Court has repeatedly upheld agamst first amendment attacks section $8(b)(4)$ of the National Labor

by the threat of violence, its effect-persons refusing to patronize a store regardless of the picketers' message-is similar to the effect of the threat of violence, because it precludes a reasoned response by those receiving the message.

For an in-depth look at the coercive aspects of labor picketing, see M. BROADWATER, LABOR and the First Amendment. Thornhill to Logan Valley Plaza 137-82 (1976).

29. McMichael v. Atlanta Envelope Co., $151 \mathrm{Ga} .776,781,108$ S.E. 226, 229 (1921). The evolution of the Supreme Court's approach to labor picketing is discussed in Note, Political Boycott Activity and the First Amendment, 91 HARv. L. REv. 659, 663-71 (1978). See also M. BROADWATER, supra note 28 , at 137-82.

30. A primary boycott of the government can also occur. For example, when a group of manufacturers agrees not to sell to the federal government unless it erects tariffs or enacts other favorable legislation they engage in a primary political boycott. See, e.g., Michigan State Medical Soc'y, 3 TRADE REG. REP. (CCH) I 21,991 (FTC Feb. 17, 1983) (physician boycott of Medicaid); United States v. Montana Nursing Home Ass'n, 1982-2 Trade Cas. If 64,852 (D. Mont. 1982) (boycott of Medicaid by nursing houne association). Whether the first amendment protects primary boycotts of the government is beyond the scope of this note.

31. 315 U.S. 722 (1942). This was one of the first cases to consider the amount of protection to be afforded to a secondary labor boycott.

32. Id. at 727.

33. Id. at 728 . 
Relations Act, ${ }^{34}$ which prohibits secondary labor picketing and boycotts. Most recently, in International Longshoremen's Association v. Allied International, Inc., ${ }^{35}$ the Court found that a longshoremen's boycott of Soviet goods in protest of the Soviet Union's 1980 invasion of Afghanistan violated section 8(b)(4) and was not protected by the first anrendment. The Court recognized that, although the union claimed to be boycotting the Soviet Union, its inenibers were actually refusing to work for their American einployers who imported Soviet goods. The union was thus engaging in a secondary boycott: although its grievance was with the Soviets, it was boycotting a third party. This was not a typical secondary labor boycott, however, for its objectives were not economic. Instead, the boycott arose out of both the longshorenren's inoral repugnance to handling Soviet goods ${ }^{36}$ and their desire to express disapproval of the Soviet Union's action. ${ }^{37}$ Thus, the boycott, like a political boycott, sought to express a nessage concerning a public issue in a way that injured others. ${ }^{38}$ Despite the boycott's expressive nature, the Court quickly disinissed the union's clain that its actions were protected by the first anjendinent. 39

The Court's decision in Allied confirms that both the federal government and the states can properly forbid secondary political boycotts, at least within the labor setting, regardless of their communicative nature. The Allied Court's reasoning seens readily apphicable to pohtical

34. 29 U.S.C. § 158(b)(4) (1976); see, e.g., NLRB v. Retail Store Employees Union, 447 U.S. 607,616 (1980)(upholding section 8(b)(4) "[a]s applied to picketing that predictably encourages consumers to boycott a secondary business"); International Bhd. of Elec. Workers v. NLRB, 341 U.S. 694, 705 (1950) (upholding section 8(b)(4)). Section 8(b)(4) states, in part, that it is an unfair labor practice for a labor organization or its agents

(i) to engage in, or to induce or encourage any individual employed by any person engaged in commerce or in an industry affectimg cominerce to engage in, a strike or a refusal in the course of his employment to use, inanufacture, process, transport, or otherwise handle or work on any goods, articles, materials, or coininodities or to perform any services; or (ii) to threaten, coerce, or restrain any person engaged in commerce or in an industry affecting commerce, where in either case an object thereof is-

(B) forcing or requiring any person to cease using, selling, handling, transporting, or otherwise dealing im the products of any other producer, processor, or manufacturer, or to cease doing business with any other person.

Labor Management Relations Act § 302(b), 29 U.S.C. § 187(b) (1976). This act provides for a private cause of action for persons lanned by secondary labor pickets and boycotts that affect commerce.

35. 456 U.S. 212 (1982).

36. Id. at 224.

37. Id. at 214 .

38. One should note that, although engaging in a boycott, the longshoremen were not seeking to express or to coerce expression directed at a domestic government. Thus, unlike most political boycotters, the longshoremen could make no claim to first amendment protection under the petition clause.

39. Allied, 456 U.S. at 227 ; see infra notes $45-48$ and accompanying text. 
boycotts: like the secondary labor boycott, the political boycott is a mode of expression that injures third parties. Additionally, political boycotts are directed, not at forcing the victim to take economic action, but at coercing his speech and association. Surely one seeking to coerce political activity should have no greater constitutional protection than one who attempts to coerce economic activity.

Thus, in cases analogous to political boycotts the Supreme Court has consistently leld that the first amendinent does not protect activity designed to coerce speech or association. These cases should serve as precedent when a court considers whether the first ainendment protects political boycotts. The cases suggest that because the political boycott is a mode of communication which coerces speech and association courts should not consider it a privileged means of expression.

\section{An Alternative Approach: The O'Brien Test}

A political boycott is not pure speech. Instead, it is expressive conduct. In United States $v . O^{\prime}$ Brien, ${ }^{40}$ the Supreme Court established a four-part test to evaluate government prohibition of expressive conduct. Governmental regulation of expressive conduct should be sustained

if it is within the constitutional power of the Government; if it furthers an important or substantial governmental interest; if the governmental interest is unrelated to the suppression of free expression; and if the incidental restriction on alleged First Amendment freedoms is no greater than is essential to the furtherance of that interest. ${ }^{41}$

Government prohibition of political boycotts appears to survive the $O^{\prime} B r i e n$ test. Both the federal and state governments have the constitutional power required by the first part of the test to prohibit conduct like that found in those political boycotts that harms businesses and coerces speech..$^{42}$ In accord witl the second part of the test, the state governments have a strong interest in protecting innocent parties from unprovoked and unjustified economic harm. More importantly, both the federal government and state governments have quite a substantial interest in protecting the free speech and association of individuals from economic coercion. ${ }^{43}$ Additionally, the representative system of government is based in large part on the premise that the govern-

40. 391 U.S. 367 (1968).

41. Id. at 377.

42. See, e.g., Allied, 456 U.S. at 222-27 (upholding prohibition of secondary labor boycott); see also supra note 34.

43. See supra notes 19-24 and accompanying text. 
ment should be responsive to the desires of the people. The government therefore has a substantial interest in guaranteeing that it is responding accurately to the political views the populace holds and not to coerced expression.

None of these interests are related to the suppression of free expression. In prohibiting or providing recovery for damages caused by secondary political boycotts the government is not seeking to ban certain ideas. It is attempting only to outlaw a mode of expression which by its nature injures third parties regardless of the ideas it happens to communicate. Thus, the third part of the test is satisfied. Finally, and consistently with the fourth requirement, a law which prohibits political boycotts does not sweep too broadly. The only way to protect boycott victims is to prohibit pohitical boycotts. Such a ban only incidentally restricts speech; would-be boycotters may still express their views through speeches, pamphlets, picketing, television cominercials or other means that seek to persuade third parties rather than to injure or coerce them. Thus, a law which is construed to prohibit political boycotts should survive the O'Brien test.

This conclusion is remforced by the Court's application of the O'Brien test in International Longshoremen's Association v. Allied International, Inc. 44 Although the Court did not explicitly state that section 8(b)(4) satisfied each portion of O'Brien, it implied that the statute survived the test. The Allied Court found that the governmental interest underlying section $8(\mathrm{~b})(4)$ includes the "protection of neutral employers and einployees from the labor disputes of others." 45 In sustaining the statute, the Court implicitly found that this interest is both substantial ${ }^{46}$ and unrelated to the suppression of free expression, and that the federal government has the constitutional power to pass such a statute. In asserting that " $[t]$ here are many ways in which a union and its individual members may express their opposition to Russian foreign policy without infringing upon the rights of others," 47 the Allied Court indicated that the statute did not sweep too broadly and that it worked only

44. 456 U.S. 212 (1982); see supra text accompanymg notes 35-38.

45. 456 U.S. at 223 n.20 (citmg NLRB v. Denver Bldg. Trades Council, 341 U.S. 675, 692 (1951)). Section $8(b)(4)$ is also mtended to preserve "the right of labor organizations to bring pressure to bear on offending employers in primary labor disputes." Id.

46. Arguably, the fact that section $8(b)(4)$ is a labor law is enough to render the underlying governinental interest substantial: the federal government has a strong interest in regulating the conduct of labor unions. That section $8(b)(4)$ is a labor law, however, should not alone satisfy the "substantiality" requirement of the O'Brien test. Congress could conceivably pass labor laws which regulate the speech of labor unions although furthering only illusory interests. More importantly, the central purpose of section $8(\mathrm{~b})(4)$ is not merely to regulate labor unions; rather, it is to protect neutral employers from economic coercion. See supra note 45 and accompanying text.

47. 456 U.S. at 227. 
an incidental restriction on the longshoremen's freedom of speech. ${ }^{48}$ Like Section 8(b)(4), a law that prohibits political boycotts furthers the governmental interest of protecting neutral parties. So long as such a law is not overbroad, it, too, should survive the O'Brien test.

\section{The Supreme Court Considers Political Boycotts: NAACP V. CLAIBORNE HARDWARE CO.}

As the previous discussion demonstrates, there is precedent for upholding state or federal laws which restrict, and even prohibit, pohtical boycotts. In the first case in which the Supreme Court was confronted with what protection to afford political boycotts, the Court ignored these analogous cases. Instead, it indicated, in dicta, that the first amendment does protect political boycotts.

In NAACP v. Claiborne Hardware Co. ${ }^{49}$ the Court reviewed a claim, under state tort law, by white merchants from Claiborne County, Mississippi, for damages they suffered from a 1966 boycott of their busmesses. The NAACP had organized the boycott to put pressure on the local town and county governments to accept its petition demanding equal legal and economic treatment for blacks. The Mississippi Supreme Court recognized that because the boycott was intended in part as an appeal for governmental action it was possibly entitled to some measure of first amendment protection. That court reasoned, however, that first amendment protection did not extend to violent conduct, and that because several of the boycotters had used violence and threats of violence to force the black community to participate in the

48. See also Osborn v. Pennsylvania-Delaware Serv. Station Dealers Ass'n, 499 F. Supp. 553 (D. Del. 1980). In Osborn gasoline dealers agreed not to sell gasoline to consumers in order to pressure the Department of Energy to raise the ceiling for their prices. Because the goal of this boycott was to force a change in governmental policy, it was a political boycott. The court noted that the Sherman and Clayton Acts were imtended to further the "strong" governmental interest in regulating anticompetitive activity, $i d$. at 558 , and "purport on their face to regulate such conduct in a manner that is unrelated to the suppression of free expression." Id. Thus the first amendment did not, under $O$ 'Brien, forbid their application to the defendants. Furthermore, because "the effect of the application of those laws would be content neutral, would not materially inhibit effective expression, and would alleviate the coercive economic impact of a concerted refusal to deal," they could constitutionally be applied to conduct such as defendant's. Id. at 557. But see Crown Cent. Petroleum Corp. v. Waldman, 486 F. Supp. 759 (M.D. Pa.) (considering the same facts and concluding that defendants were protected from Sherman Act liability by the first amendment), rev'd on other grounds, 634 F.2d 127 (3d Cir. 1980).

For further discussion of $O^{\prime}$ Brien in the boycott context, see Kennedy, Political Boycotts, the Sherman Act, and the First Amendment: An Accommodation of Competing Interests, $55 \mathrm{~S}$. C AL. $\mathrm{L}$. Rev. 983, 1010-13 (1982); Note, Protest Boycotts Under the Sherman Act, 128 U. P. L. Rev. 1131, $1144-48$ (1980).

49. 458 U.S. 886 (1982). 
boycott, the boycott was not privileged. ${ }^{50}$ The United States Supreme Court agreed that "violent conduct is beyond the pale of constitutional protection" 51 and held that the defendants who had used violence could be held responsible for resulting damages. 52 The Court, however, reversed the state court's holding that the boycott's violence was sufficiently widespread to justify overriding the boycotters' first amendment claims and imposing liability for all damages fiowing from the boycott on all of the participants. Such a holding, the Court found, was simply not precise enough as to the basis of each defendant's liabitity to satisfy the requirements of the first amendment. ${ }^{53}$

The Claiborne Court then stated that "the nonviolent elements of [the boycotters'] activities are entitled to the protection of the First Amendment." 54 In light of the narrow and seemingly uncontroversial rationale for reversing the Mississippi Supreme Court, Claiborne's discussion of whether the nonviolent aspects of the boycott were protected by the first amendment seems to be dictum. Nevertheless, because of its sweeping assertions witl regard to political boycotts, Claiborne could easily come to stand for the proposition that all peaceful boycotts directed at obtaining governmental action are protected by the first amendment. ${ }^{55}$

\section{A. Claiborne's Rationale: Peaceful Political Activity is Privileged.}

Although Claiborne recognized the primary, rather than secondary, aspects ${ }^{56}$ of the protest, it did not focus on their constitutional significance. Instead, the Court indicated that the peaceful aspects of the boycott were privileged because "a niajor purpose of the boycott ... was to infiuence governmental action." 57 The Court also focused

\section{Id. at 894-96.}

51. Id. at 933 .

52. Id. at 926 .

53. Id. at $918-20$.

54. Id. at 915.

55. See supra notes 7-38 and accompanying text.

56. See supra note 30 and accompanying text.

57. 458 U.S. at 914. The Court noted that defendants' petitiou to the town and county governments was amended to mclude a demand that all stores "employ Negro clerks and cashiers." Id. at 899-900. The boycott, although secondary in that it demanded that its victims join the boycotters in pressuring the government, was primary with regard to those demands made on the merchants relating to the operation of their busimesses.

Although it appears that no cases have so held, most courts have indicated that peaceful primary noncommercial boycotts are protected by the first aunendment. See Organization for a Better Austin v. Keefe, 402 U.S. 415,419 (1971)("The claim that the expressions were intended to exercise a coercive inpact on respondent [the victim of pamphleting] does not remove them from the reach of the First Amendment."); Searle v. Johnson, 646 P.2d 682, 685 (Utah 1982); see also Van Alstyne, A Graphic Review of the Free Speech Clause, 70 Calif. L. Rev. 107, 134 n.46 (1982). 
on the organizational efforts of the defendants, efforts which included speeches and picketing. In reference to these "speech" aspects of the boycott, the Court held that the state had no "right to prohibit peaceful political activity such as that found in the boycott in this case." 58 In other words, the Court focused on the speeches taking place within the boycott in order to protect the entire boycott. The plaintiffs in Claiborne did not, however, seek to impose hability solely on the basis of defendants' speech as "speech." Rather, the plaintiffs had alleged that they were damaged by defendants' conduct-the boycott-as well as by defendants' speech in furtherance of that conduct. ${ }^{59}$

Although the government cannot constitutionally prohibit political speech as such, the presence of political activity does not always innnunize a course of conduct. Political speech otherwise constitutionally protected is not privileged when used in furtherance of an illegal objec-

The boycotters in Claiborne, because of the peculiar mixed nature of their boycott, could have asserted two separate first amendinent defenses. Thus, even if the Supreme Court had held that the secondary-political aspects of the boycott did not provide immunity under the first amendment, the defense that the boycott was primary and noncommercial might well have succeeded.

The Claiborne Court also observed that "[m]any of the owners of these boycotted stores were civic leaders in Port Gibson and Claiborne County," 458 U.S. at 889 n.3; see also id. at 892 n.8, suggesting that the boycott im Claiborne was im part a primary boycott of "civic leaders" or public officials to protest policies for which they were responsible. A primary governmental boycott is, however, a direct boycott of the government and not, as was the case here, a boycott of the private businesses of government officials. Moreover, it is unlikely that the first amendment protects atteinpts to imfiuence governmental activity by coercive activity directed at governmental leaders in their private capacity. See supra note 30.

58. 458 U.S. at 913 (emphasis added).

59. This claim distinguishes Claiborne from the Noerr line of cases. See Eastern R.R. Presidents Conference v. Noerr Motor Freight, Inc., 365 U.S. 127 (1961), cited in Claiborne, 458 U.S. at 913. These cases stand for the proposition that joint efforts by members of an industry to persuade the government to act in order to help that industry are not subject to the Sherman Act, 15 U.S.C. $\S \S 1-7$ (1982), and may be protected by the first amendment as petitions of the government. See Noerr, 365 U.S. at 137-44; Lafayette v. Louisiana Power \& Light Co., 435 U.S. 389,399 (1978); California Motor Transp. v. Trucking Unlimited, 404 U.S. 508, 509-11 (1972); United Mine Workers v. Pennington, 381 U.S. 657, 669-71 (1965). The defendants im these cases petitioned the government through pure speech; they did not seek to organize boycotts of private parties. See Noerr, 365 U.S. at 142 ("There are no specific findings that the [defendants] attempted directly to persuade anyone not to deal with the [plaintiffs]."). Thus, plaintiffs were damaged by the message defendants were trying to express to the government. Prolibiting the speech because of its content therefore may well have violated the first amendinent, as it "would have involved government control of the marketplace of ideas." Osborn v. Pennsylvania-Delaware Serv. Station Dealers, 499 F. Supp. 553, 557 (D. Del. 1980); see also Sierra Club v. Butz, 349 F. Supp. 934 (N.D. Cal. 1972)(the first amendment protects individuals who, by the content of their speech, induced the government to breach a contract with the plaintiff). The political boycott, in contrast to Noerrtype speech, is composed of expressive conduct that damages individuals regardless of the message a particular boycott is intended to convey. Thus, because governmental prohibition of political boycotts is directed at the harmful ineans of conduct rather than at the expression of a particular idea, Noerr is not dispositive. See Osborn, 449 F. Supp. at 557; Searle v. Jolınson, 646 P.2d 682, 688-89 (Utah 1982). 
tive. ${ }^{60}$ Just as individuals are not immune from criminal liability because they use political speech to encourage or to organize riots or murders im the name of a political goal, boycott organizers who couple political speech with an otherwise illegal boycott ${ }^{61}$ are not necessarily immune from liability resulting from that boycott. Thus, the Claiborne defendants' claim of first ainendment privilege should liave been sustained only if the boycott itself could not constitutionally be prohibited.

\section{B. Claiborne's Misapplication of the O'Brien Test.}

Because the boycott in Claiborne was expressive conduct, ${ }^{62}$ the Claiborne Court used the O'Brien test to determine the constitutionality of the Mississippi law prohibitimg the boycott. In applying the O'Brien test, the Court cited ${ }^{63}$ Missouri $v$. National Organization for Women, Inc. ${ }^{64}$ in which the United States Court of Appeals for the Eighth Circuit considered whether the National Organization for Women (NOW) was liable under the Sherman Act and state tort law65 for organizing a political boycott. NOW's convention boycott of Missouri hotels had the sole purpose of forcing those hotels to pressure the Missouri state legislature to ratify the Equal Rights Amendment. ${ }^{66}$ The

60. See, e.g., Giboney v. Empire Storage \& Ice Co., 336 U.S. 490 (1949). The Giboney Court stated that

it has never been deemed an abridgement of freedom of speech or press to make a course of conduct illegal merely because the conduct was in part initiated, evidenced, or carried out by means of language. . . . Such an expansive interpretation of the constitntional guarantees of speech and press would make it practically impossible ever to enforce laws against agreements in restraint of trade as well as inany other . . . conspiracies deemed injurious to society.

Id. at 502 (citations ornitted); see also National Soc'y of Professional Eng'rs v. United States, 435 U.S. 679, 697 (1978)("While the resulting order may curtail the exercise of liberties that the Society unight otherwise enjoy, that is a necessary and, in cases such as this, unavoidable consequence of the violation . . . .); Note, Protest Boycotts Under the Sherman Act, 128 U. PA. L. REv. 1131, 1161-63 (1980). But see Note, Political Boycott Activity and the First Amendment, 91 HARv. L. REv. 659, 679-83 (1978)(arguing that a prohibition of efforts to encourage third parties not to deal with a business is unconstitutional content regulation).

61. The Mississippi Supreine Court held that as a matter of state law the boycott was illegal. See Claiborne, 458 U.S. at 894-95. The only qnestion before the Supreme Court was whether this otherwise illegal boycott was protected by the first amendment. Id. at 906-07.

62. Id. at 911 .

63. Id. at 914 n.48.

64. 620 F.2d 1301 (8th Cir.), cert. denied, 449 U.S. 842 (1980).

65. The common law tort in NOW was "intentional infliction of harm without legal excuse," a tort which the court stated allows recovery against one who has "intentionally interfere[d] with a contract or a prospective contractual relation of another." 620 F.2d at 1316. This tort is thus virtually identical to the one considered in Claiborne. In fact, both torts have been lumped together with other similar torts under the heading of "interference with prospective advantage." See Estes, Expanding Horizons in the Law of Torts-Tortious Interference, 23 DRAKE L. REV. 341, 342-44 (1974).

66. $620 \mathrm{~F} .2 \mathrm{~d}$ at $1302-03$. 
NOW court held that NOW was protected from common law tort liability by the first amendment's petition clause. Applying the O'Brien test, the NOW court lield that "the riglit to petition is of such importance that it is not an improper interference [under state tort law] even when exercised by way of a boycott." 67 Thus, the court balanced the boycotters' interest im free speech with the state's interest in prohibiting the boycott ${ }^{68}$ and found that the boycotters' interest outweiglied the state's interest. Undertaking a similar balancing, Claiborne held that "the right of the States to regulate economic activity could not justify a complete prohibition against a nonviolent, politically-ınotivated boycott designed to force governmental and economic change . . . ."69

Unlike many constitutional tests, lowever, the $O^{\prime} B r i e n$ test is not one which balances interests. The $O^{\prime} B r i e n$ test requires instead that a law manifest four separate qualities to survive a first ainendment attack. $^{70}$ Thus, Claiborne, like NOW, misapplied the $O^{\prime} B r i e n$ test to the state law being challenged. Had the Court retamed a nonbalancing approach, it probably would have concluded that the law cliallenged in Claiborne survived the $O^{\prime}$ Brien test. $^{71}$

\section{Claiborne's Failure to Distinguish Allied.}

Recognizing Claiborne's apparent inconsistency witl Allied, ${ }^{72}$ the Claiborne Court indirectly attempted to reconcile the two cases. First, the Claiborne Court tried to limit its holding by distinguishing in a footnote between a claim brought in tort, as in Claiborne, and one brought under a statute, such as the claim in Allied: "We need not decide in this case the extent to whicli a narrowly tailored statute designed to prohibit certain forms of anticompetitive conduct or certain types of secondary pressure may restrict protected First Amendment activity." 73 The distinction fails to resolve the inconsistency, however. The most likely inference to be drawn from the Court's stateinent is that the common law tort it considered in Claiborne was overbroad. ${ }^{74}$

67. Id. at 1317. This language was quoted with approval in Claiborne. 458 U.S. at 914 n.48.

68. See also Crown Cent. Petroleum Corp. v. Waldman, 486 F. Supp. 759, 769 (M.D. Pa.)(the boycotters' "imterest in free expression . . . outweighs the interest in free trade and unrestrained competition [embodied in the Sherman Act]"), rev'd on other grounds, 634 F.2d 127 (3d Cir. 1980).

69. Claiborne, 458 U.S. at 914.

70. See supra notes $40-41$ and accompanying text.

71. See supra notes $42-48$ and accompanying text.

72. International Longshoremen's Ass'n v. Allied Int'l, Inc., 456 U.S. 212 (1982); see supra notes 35-39 and accompanymg text.

73. 458 U.S. at 915 n. 49 .

74. For cases imvolving overbreadth, see, e.g., Gooding v. Wilson, 405 U.S. 518 (1972); Coates v. Cimcinnati, 402 U.S. 611 (1971); NAACP v. Alabama ex rel. Flowers, 377 U.S. 288 (1964). See also Note, The First Amendment Overbreadth Doctrine, 83 HARv. L. Rev. 844 (1970). 
This reading is not borne out by the Claiborne opinion, however, for it simply did not use overbreadth as a rationale..$^{75}$ The Court held, not that the tort was overbroad, but that the boycotters' nonviolent "activities are entitled to the protection of the First Amendinent."76 In both Allied and Claiborne, however, the defendants engaged in the same activity: a boycott intended as expressive pohitical conduct. Both the statute in Allied and the tort law in Claiborne were construed to prohibit that conduct. Thus, Claiborne's distinction between a common law cause of action and a narrowly drawn statutory cause of action seems unsatisfactory.

Claiborne also sought to distinguish Allied on the basis of the nature of the activity being regulated. In Claiborne the Court cited Allied as an exainple of a case $m$ which the "Court has recognized the strong governmental interest in certain forms of economic regulation, even though such regulation may have an incidental effect on rights of free speech and association."77 Claiborne then held that "[w]hile States have broad power to regulate econormic activity, we do not find a comparable right to prohibit peaceful pohtical activity such as that found im the boycott in this case."78 This distinction between economic activity in Allied and pohtical activity in Claiborne is specious, however. In fact, the Court itself undercut this distinction by explicitly recognizing im Allied that the longshoremen's boycott had a "political objective"79 and by noting that the "distinction between labor and political objectives would be difficult to draw in many cases." 80 As the predominant purpose of the boycotts in both Allied and Claiborne was expression, the cases are fundamentally indistimguishable.

Dean Harry Wellington has noted that one explanation for Claiborne's inconsistency with Allied is that the Court based its decisions on the speaker's identity: "[L]abor unions ordinarily are organizations dedicated to econormic activity and . . economic activity is subject to substantial governmental regulation," whereas the "NAACP is often . . . a political action organization and political action is rightly subject

75. Furthermore, the fact that the overbreadth doctrine has been losing favor as a means of constitutional adjudication contributes to the conclusion that Claiborne was not decided on the basis of overbreadth. See, e.g., Parker v. Levy, 417 U.S. 733, 756-57 (1974); Arnett v. Kennedy, 416 U.S. 134, 159-62 (1974); Broadrich v. Oklahouna, 413 U.S. 601, 611-18 (1973). But see Oregon v. Robertson, 293 Or. 402, 649 P.2d 569, 589-90 (1982)(statute prohibiting "coercion" overbroad).

76. 458 U.S. at 915 (emphasis added).

77. Id. at 912.

78. Id. at 913 .

79. 456 U.S. at 225 .

80. Id. 
to substantial government protection." 81 The Supreme Court in fact distinguished the two cases, not only by the identity of the speaker, but also, it seems, by the views the speaker expressed. In Allied the Court did not seem to find the union's message particularly compelling and focused principally on the secondary boycott as a means of expressive conduct. ${ }^{82}$ In contrast, the Court in Claiborne not only noted the general political activity of the boycotters, but expressed its sympatlyy with the content of the boycotters' message. The Court remarked that the boycotters "sought to bring about political, social, and economic change. Through speech, assembly, and petition-rather than through riot or revolution-petitioners sought to change a social order that had consistently treated them as second-class citizens." 83 The Court further stated that the boycotters

sought to vindicate rights of equality and of freedoin that lie at the heart of the Fourteenth Amendment itself. The riglit of the States to regulate economic activity could not justify a complete prohibition against a nonviolent, politically-motivated boycott designed to force governmental and economic change and to effectuate rights guaranteed by the Constitution itself. ${ }^{84}$

Although the government can constitutionally regulate certain forms of expressive conduct, ${ }^{85}$ it may not generally determine who may speak or what may be said. Regulation of expression inust usually be neutral with regard to both speaker and content. ${ }^{86}$ Claiborne violated this principle by basing its holding that the defendants were protected by the first amendment on both the identity of the speaker and the

81. H. Wellington, Remarks at Yale Law School Alumni Weekend (Oct. 23, 1982)(copy on file with author).

82. 456 U.S. 212,223 (1981).

83. 458 U.S. at 912.

84. Id. at 914.

85. See United States v. O'Brien, 391 U.S. at 376 ("We cannot accept the view that an apparently limitless variety of conduct can be labeled 'speech' whenever the person engaging im the conduct intends thereby to express an idea.").

86. There are certain and well known exceptions to the rule that regulation of speech may not be content-related. Thus, a state may prohibit "fighting words," Cliaplinsky v. New Hampshire, 315 U.S. 568, 572 (1942), and regulate pornography, Miller v. California, 413 U.S. 15, 23 (1973), and defamation, New York Times Co. v. Sullivan, 376 U.S. 254 (1964). But the type of speech found in Claiborne and Allied - speech concerning public issues or political speech-is not an area of expression which the government can regulate according to content. See, e,g., Police Dep't. v. Mosley, 408 U.S. 92, 95 (1972) ("above all else, the First Amendment means that governinent lias no power to restrict expression because of its inessage, its ideas, its subject matter, or its content"); Cohen v. California, 403 U.S. 15, 24 (1971)(noting the "usual rule that governmental bodies may not prescribe the form or content of individual expression"); see also Stone, Restrictions on Speech Because of its Content: The Peculiar Case of Subject-Matter Restrictions, 46 U. CHI. L. REv. 81 (1978). 
content of the message expressed, rather than on an objective analysis of the pohitical boycott as a form of expression.

Although Claiborne reached the appealing result of protecting an appeal for racial equality, it did so by using faulty first amendment analysis. Claiborne should simply have held that the violence surrounding the boycott was not sufficient to reinove any first amendment protection. The Supreme Court should have resisted the temptation to state that the peaceful organizing activities and the boycott itself were privileged as political activity, for in so doing the Court lias created the danger that Claiborne will come to stand for the proposition that the first amendment protects all political boycotts, regardless of the nature of their goals.

\section{CONCLUSION}

Like parades, pamphleting, and picketing, political boycotts can be used by any speaker to express a desire for governmental action. The political boycott is thus only one of a number of modes of expression. Although federal and state governments cannot, in general, constitutionally ban the expression of particular views or ideas, ${ }^{87}$ they can regulate or prohibit harmful means of expressing those views, without offending the first amendment.

Because a political boycott deprives its victims of their own freedom of speech and association, it should not be considered a protected means of speech. The immediate goal of a political boycott is to force its victims, private parties, to express themselves politically. The coercive power of a political boycott slould not be underestimated. Merchants depend on sales for their livelihood; an effective boycott of their stores deprives them of their source of income. ${ }^{88}$ Although attempts to persuade individuals to act are usually protected by the first amendment, attempts to coerce individuals to act are not so immunized. 89 As the Supreme Court has noted, the "right of free speech of

87. See supra text accompanying note 86 .

88. Twelve of the plaintiff merchants in Claiborne suffered a combined loss of $\$ 944,699$ as a result of the mixed primary and secondary political boycott at issue in that case. 458 U.S. at 893.

89. That pohitical boycotts deprive their victims of first amendment-like rights is demonstrated by cases in which labor unions acting under color of state law have attempted to coerce speech and association by private individuals. In Abood v. Detroit Bd. of Educ., 431 U.S. 209, 234-37 (1977), the Court recognized the right to refrain from association and held that nonmeinbers of a labor union, who are required by federal law to remit a service fee to the union for its bargaining services, have a constitutional right to forbid the union from using those fees for political purposes. Similarly, Justice Douglas stated in International Ass'n of Machinists v. Strcet, 367 U.S. 740, 777 (1979)(Douglas J., concurring), that "[s]mce neither Congress nor the state lcgislatures can abridge [First Amendment] rights, they cannot grant the power to private groups to abridge thein." 


\section{... [an] individual does not embrace a right to snuff out the free speech of others."90}

Claiborne's dictum that a peaceful political boycott is privileged should be given no precedential value because the Supreme Court failed to consider the first amendment question fully and objectively. Modes of expression whicl coerce speech or association are not privileged, for they deprive individuals of their first amendment freedom to refrain from speech and association. The victims of political boycotts are financially coerced to express theinselves politically, regardless of whether they hold the views they are forced to express, whether they desire to make their own views known, or whether they wish to associate with the boycotters. Because of these harmful side effects, courts

The District Court for the District of Columbia, in Kolinski v. UAW, 530 F. Supp. 728 (D.D.C. 1982), recently extended Abood, holding that "a union may not require a non-member, as a condition of receiving strike benefits, to march in a picket line . . . when he would not choose to do so voluntarily and did not take part in the union's decision to strike and picket." Id. at 733. The Kolinski court held that it also was an unconstitutional infringement on the nonmembers' freedoms of speech and association, as well as a violation of 29 U.S.C. $§ 157$ (1976)(which guarantees employees the right to organize and to refrain from organizing), to condition a nonmember's receipt of strike benefits on some alternative form of service, such as working in a strike kitchen; the nonmember had already paid for the benefits in the service fee and the "sole and ultimate utility [of the alternative service] is the advancement of the union's message." $530 \mathrm{~F}$. Supp. at 733. The court distinguished this situation froln conditioning a member's receipt of benefits on his involvement in strike activities: "by exercising his choice to become a member . . . and participating in its decision-making process, a nember of a union accepts as his own, to the extent that he is a part of that group, the position of the umion on the question of whether to strike." Id. at 733.

Courts have also protected union members from union efforts to control their individual political activities. The court in Mitchell v. International Ass'n of Machinists, 196 Cal. App. 2d 796, 16 Cal. Rptr. 813 (1961), for instance, held that a union unconstitutionally deprived a meniber of his first amendinent rights when it penalized him for engaging in pohitical activity that the union opposed. Thus, although a union may require its members to strike, NLRB v. Allis-Chalmers Mfg. Co., 388 U.S. 175 (1967)(a union can fine members who do not honor authorized strikes), it cannot constitutionally control its members' individual political expression. The union in Dudek v. Pittsburgh Fire Fighters, 426 Pa. 233, 228 A.2d 752 (1967), went one step further: it required its members to engage in political activity, the picketing of a political candidate. The court noted that "the Umion in this case . . . argues that to require members to exercise public speech through picketing is not to deny freedoin of speech but to implement it. However, the [union] fails to realize that the right to speak carries with it its inevitable counterpart, the right not to speak." $425 \mathrm{~Pa}$. at 239, $228 \mathrm{~A} .2 \mathrm{~d}$ at 755.

90. Red Lion Broadcasting v. FCC, 395 U.S. 367, 387 (1969). In Searle v. Jolunson, 646 P.2d 682 (Utah 1982), the Supreme Court of Utah adopted this reasoning in holding that political boycotts are not protected by the first amendinent. The court remarked that "when mjury is caused to a disinterested party, not by the subject matter of the expressions themselves, but by the means used to achieve such expressions, the First Amendnient confers no absolute privilege." Id. at 689. The court therefore held that the defendants' claim of first amendinent protection would fail if defendants "specifically intended to injure [plaintiffs"] busimesses im order to coerce them to join in defendants' petitioning efforts." Id. 
should not afford political boycotts protection under the first amendment.

Gordon M. Orloff 